DOI: 10.20472/IAC.2017.034.033

\title{
RADOSTINA MIHALEVA
}

Sofia University Kliment Ohridski, Bulgaria

\section{NEW HUMANISTIC METHODS IN FOREIGN LANGUAGE TEACHING - SUGGESTOPEDIA - DESUGESTOPEDIA}

\begin{abstract}
:
This article provides a brief review of the basics and the advantages of Suggestopedia-Desuggestopedia (Reservopedia), the Bulgarian contribution to the world's educational methodology, one of the most humane and the most effective of all.

Suggestopedia-Desugestopedia is a non-manipulative method of learning both in foreign languages and in any other subjects for all ages at the level of reserves - potential, unused brain / mind capacities. This means at least three to five times faster, easier and deeper training, internal freedom, increased motivation to learn, joyful training and healing or prophylactic effects.

Suggestopedia-Desuggestopedia aims to tap the hidden potential of human abilities, especially memory and intellect, and in a pleasant and beneficial way to facilitate the learning process. To do so, it is necessary to apply the seven laws of Suggestopedia simultaneously, namely love, freedom, the teacher's conviction that something extraordinary is happening, the increased teaching material, partial-global proportion, the golden proportion and the application of classical art and aesthetics.
\end{abstract}

\section{Keywords:}

Suggestopedia-Desuggestopedia; Dr. Georgi Lozanov; Bulgaria; seven laws; reserves; reservodpedia

JEL Classification: 129 


\section{Introduction}

The creator of this new methodology is the Bulgarian scientist Dr. Georgi Lozanov. His contribution to humanity has been and will be estimated highly. Suggestopedia dates back to 1966 when Dr. Lozanov set up his Institute of Suggestology and started teaching his methodology to both Bulgarian and foreign teachers. The institute proved to be the only institution in Bulgaria possessing the most modern and high tech equipment at the time.

Suggestopaedia is a comparatively new methodology seeking ways to an unprogrammed, uninhibited, and spontaneous release of the reserve capacities (unused capacities) of the human brain/mind, suppressed by social suggestive norms. Desuggestology is a science of spontaneous, not forced release from inhibiting, limiting and impairing influences.

The name Suggestopedia-Desuggestopedia derives from the verb 'to suggest' meaning 'to offer' or 'to propose'. This renders the essence and one of the main messages of Suggestopedia, i.e. nothing in the learning process is imposed but it comes naturally. On the other hand, as the new methodology helped release the hidden reserves Dr. Lozanov's dream was to call it 'Reservopedia' and it to be known by the world as Reservopedia. And he did call it Reservopedia in his last publications. However, the world has been familiar with the name Suggestopedia for decades.

Suggestopaedia-Desuggestopedia constantly follows seven laws:

1. Active love for the human being.

The reserves of a personality can be discovered, recovered and activated only by means of love. Love is present at the very beginning when the teacher delicately involves the students in a game in which he/she acts together with them, just as a mother plays with her children. That game will continue throughout all the stages, in different forms, to the end of the course.

2. Freedom of personality.

Freedom of personality and personal choice is well respected. Nobody has ever been programmed in terms of time and activity. Everybody has their own free and conscious self control and will.

3. Conviction of the teacher in the final results.

This is the conviction that something extraordinary, different from the social suggestive norm, is taking place with no failure, and will lead to the state of inspiration of the teacher. The students have the feeling that they achieve everything on their own.

4. Manifold increase of input volume. 
The study material presented to students in a specific time frame, must be, as a minimum, at least 2 to 3 times (times, not percent) larger in size than the existing established norm by the other methodologies.

5. Global-partial, partial-global; partial through global.

In Suggestopaedia-Desuggstopedia those two are acquired simultaneously. Never acquire first the elements, and then their union in meaningful units. Acquire simultaneously the element and its place in a meaningful unit.

6. The golden proportion.

The golden proportion has been for centuries recognized as the greatest harmony in nature.

The formula of the golden proportion is the following:

$$
\begin{aligned}
& (a-x) / x=x / a \\
& x^{2}+a x-a^{2}=0 \\
& x=0,6180339
\end{aligned}
$$

7. Use of classical art and aesthetics.

Reservopaedic art creates conditions for optimal psycho-relaxation and harmonious states which help create a spontaneously increased acquisition state and enhance the capacity to tap the reserves of mind in a pleasant atmosphere.

The above mentioned laws are so closely intertwined that they must be simultaneously respected at all times during the teaching process.

The general lesson structure is a four-stage training programme:

- Introduction.

At the teacher's very first contact with the students, he/she introduces a spirit of easiness into his/her attitude towards the group as a whole and towards each student as an individual. The teacher now stimulates the students to join immediately and willingly in a common game-project. The game-project frees them from boredom, demotivation and fear of learning. Imitating the teacher, the students assume their new roles.

- Concert sessions /active, passive/.

- Active

The musical compositions for the active session are emotional, with a wealth of melody and harmony in them. The teacher waits quietly until the end of the introduction of the piece. After a clearly perceivable caesura (a breath, a short pause), reading of the text begins, the teacher's intonation varying solemnly according to the character of the musical piece. 
- Passive.

Here the musical compositions are characterised by austerity of form, content, and intellectual depth. The reading is normal, like everyday speech, and as artistic as the dialogue requires. The speed of reading should be that of the colloquial speech of the respective foreign language. In this session, the music is used mainly as a background.

- Reading.

The text is divided into several parts. The reading of the first dialogue/text/ is performed in chorus. The students read the parts in the foreign language, taking a look at the translation of the text. Various alterations with the voices of the teacher and the students are to be organised.

- Elaboration and students' production.

Every day the elaboration starts with a song and finishes with a song. The group goes on with the work begun the previous day until they get through the grammatical units in the lessons. The students are immediately activated by reading and translating in a playful manner, briskly, and frequently changing the games. All this is done in the respective double plan.

Two days before the introduction of the next chapter the students are assigned a creative task to do.

Dr. Georgi Lozanov's numerous experiments at his Institute of Suggestology affiliated to the Ministry of Education at the time, and the results acquired by all the students who studied at the institute confirmed that SuggestopediaDesuggestopedia is an effective and humanistic methodology and it has a number of advantages:

- It creates positive attitudes and motivation in learners.

- They can use their hidden reserves and overcome the social suggestive norms.

- They can eliminate the fear of failure and mistakes by assuming new identities.

- Suggestopedia-Desuggstopedia stimulates communication by converting monologues to dialogues without overemphasizing mistakes but with delicate correction.

- It has a positive effect on the development of personality.

- It has a humanistic impact on mankind. 
In 1978, from $11^{\text {th }}$ December until $17^{\text {th }}$ December the observations and conclusions of twenty UNESCO experts from all over the world visiting Dr. Lozanov's Institute and the experimental Suggestopedic primary schools in Sofia, also confirmed that Suggestopedia-Desuggestopedia is an effective and humanistic methodology and recommended the following:

1. There is a consensus that Suggestopaedia is a generally superior teaching method for many subjects and for many types of students, compared with traditional methods.

2. Standards should be set for the training, certification and maintaining of standards of Suggestopedic training.

3. Different categories of competency of teachers should be used to reflect increasing levels of teaching performance in certification.

4. Suggestopedic teacher training should be started as soon as possible.

5. An International Association for Suggestology and Suggestopedia that is affiliated to UNESCO should be set up and should have the assistance and guidance of Dr. Lozanov for training, research, coordination and publication of results.

Today, Suggestopedia-Desuggestopedia is well-known all over the world. We are lucky that we still have some of the teachers who worked with Dr. Lozanov at his Institute, and can be a great support and inspiration for the young enthusiastic disciples, such as Mrs. Zlatka Dumeva, Mrs. Reni Nacheva and Mrs. Angelina Karaslavova.

Suggestopedic Centres operate on all continents. It is worth mentioning the efforts, inspiration and strives of our Norwegian colleagues, Mrs. Lisa Hartmark, in particular. She is the most energetic person I have ever met in my life. Owing to her incredible commitment and conviction in Suggestopedia-Desuggestopedia she managed to both set up quite a number of Suggestopedic centres teaching Norwegian to immigrants all over Norway and make Suggestopedia-Desuggestopedia a governmental policy recognized by the Norwegian state.

The Bulgarian contribution to the world heritage in the sphere of education is Suggestopedia-Desuggestopedia.

\section{Reference}

ЛОЗАНОВ, ГЕОРГИ (2005). Сугестопедия-десугестивно обучение. София ЛОЗАНОВ, ГЕОРГИ (1971). Сугестология. София 
LOZANOV, GEORGI (2009). Suggestopedia - Reservopedia: Theory and Practice of the Liberating-stimulating Pedagogy on the Level of the Hidden Reserves of the Human Mind. Sofia

LOZANOV, GEORGI Suggestology and Suggestopedia, (issue 2, 1975) Monthly Magazine of Science Institute of Suggestology. Sofia

RICHARDS, JACK C. and ROGERS THEODORS S. (1986). Approaches and Methods in Language Teaching. A description and analysis. Reprint 1992. Cambridge 